\title{
Towards A Framework for Development of Operational and Maintenance Cost Model of Highway Project in Malaysia
}

\author{
Monirul Islam, Sarajul Fikri Mohamed, Syamsul Hendra Mahmud, Alghamdi Khalid Ahmed \\ M, Karban Abdullah Saeed
}

\begin{abstract}
A major role of cost model is to ensure that the resource being handled is maintainable, functional and secure. The last decade has shown that attention to the idea of cost model added value to accomplish this management. In the context of cost model research and practice, the purpose of this paper is to identify, compare and describe the different cost models and investigate their value parameters. A systematic literature review of various publications has been followed in order to categorize the different theoretical models and to analyze the key quality parameters in the cost model. The established eight theoretical models were described in the sense of cost and the variant research projects and structures have taken into account very diverse parameters. In cost models, this analysis organizes 11-various quality parameters into four relevant headings: individuals, system and material, economy and social. Among all value parameters, cost reduction and customer satisfaction, followed by efficiency, are the most prioritized value parameters. This paper results provide a sound basis and realistic interpretation of future research to harmonize the definition of cost model added value as it is based solely on literature review.

Keywords: Cost Model; Highway Maintenance; Highway Project; Maintenance costs; Maintenance issues.
\end{abstract}

\section{INTRODUCTION}

Malaysia is currently being considered in the intermediate development and industrialization phase, with the development of many construction mega-projects in progress. For the economic development of a country, the construction industry has a wide-ranging connection with the rest of the economy, for example, the manufacturing industry and financial services industry. This industry is responsible for building the nation's physical infrastructure, providing transportation services, housing facilities, business and various educational and commercial institutions. Over the past decade, the Malaysian construction industry has

Revised Manuscript Received on January 03, 2020.

* Correspondence Author

Monirul Islam, Department of Quantity Surveying, Faculty of Built Environment, University Teknologi Malaysia, Johor Bahru, Malaysia, monir176@gmail.com

Sarajul Fikri Mohamed, Department of Quantity Surveying, Faculty of Built Environment, University Teknologi Malaysia, Johor Bahru, Malaysia,sarajul@utm.my

Syamsul Hendra Mahmud, Department of Quantity Surveying, Faculty of Built Environment, University Teknologi Malaysia, Johor Bahru, Malaysia, b-syamsul@utm.my

Alghamdi Khalid Ahmed M, Umm Alqura University, College of Engineering and Islamic Architecture, oraijart@gmail.com

Karban Abdullah Saeed, Umm Alqura University, College of Engineering and Islamic Architecture, Arch-ask@hotmail.com

(C) The Authors. Published by Blue Eyes Intelligence Engineering and Sciences Publication (BEIESP). This is an open access article under the CC BY-NC-ND license (http://creativecommons.org/licenses/by-nc-nd/4.0/) contributed significantly to the economy as an enabler of

growth to other industries, more specifically construction industry contributes to national economy 3-5\% [1]. The global markets for Architecture, Engineering and Construction (AEC) are forecast to grow from 2016 to 2021 at a rate of 5.50 percent. The construction industry in the United Kingdom (UK) is expected to reach US\$ 208 billion by 2020 and growth is expected to continue at about 3\% [2]. Qatar, Mexico and India's construction industries are estimated to be worth US\$ 59 billion, US\$ 144.90 billion, and US\$ 563.40 billion, respectively, over the same period. Malaysia's Construction Industry Development Board (CIDB) announced that it invested US\$ 28.72 billion, US\$ 32 billion in 2016 in 2015 and predicted that it would be US\$ 70 billion in 2018. In addition, CIDB has recorded double-digit growth, almost 12.7 percent since 2011. Highway construction is considered an essential component of the construction industry in Malaysia and forms about 35.4 percent of the total construction work [1]. Allocation for new Highway projects is US\$710 million in 2018. In 2016, Malaysia largest project PLUS Malaysia Bhd spent about RM1 billion for preserving about 5,000 kilometers of highways in the country [3]. According to [4], $60 \%$ of the total construction budget in most developed countries has been spent on repair and maintenance. [5] states that 55\% of the total cost over a span of forty years are for operation and maintenance costs. $75 \%$ of the toll collected by the concession companies went to debt servicing while $20 \%$ is spent on maintenance and overheads. The Government of Malaysia has allocated a huge budget to improve and maintain the current road condition, where from 2001 to 2010 approximately RM5 billion was spent on the maintenance and rehabilitation of all federal roads in Malaysia [6], [7]. For instance, there was an increase of 29 percent in the number of maintenance contracts awarded from 2013 to 2015. In 2013, 1337 contracts for maintenance were awarded, while in 2015 the number rose to 1725 . In terms of value, maintenance spending in 2015 amounted to approximately US\$ 3.40 billion, representing about 10 percent of total construction costs. It had risen to US\$ 3.745 billion in 2016 .

This highlights a sector allocation increase of 10.15 percent compared to 2015. This research focuses on creating a framework for engaging design factors and criteria during the design phase of highway projects, helping to maximize benefits and promote cost-effective maintenance practices. Design of the template needs to identify and evaluate the design issues posed by the facility manager during the design phase, which will have major potential impacts on road maintenance.

\section{Published By:}

Blue Eyes Intelligence Engineering \& Sciences Publication

(C) Copyright: All rights reserved. 


\section{LITERATURE REVIEW}

\section{A. Overview of Operation and Maintenance Cost}

Maintenance has three main problems: weak financial management, incompatible management and poor design [8]. Infrastructure defects occur from incorrect design specifications and construction and will be responsible for the maintenance management effects. Today, deficiencies considered by both owners and contractors are the most crucial factor for project performance and have a tremendous impact on later expenditure such as post-occupancy. According to a survey report, design flaws are also the major risk in the construction industry in Kuwait, Japan, the United States of America (USA) and Hong Kong [9]. A study by [9] shows that Due to faulty design decisions, maintenance costs can be increased by 14.20 percent. [10] also revealed that the cost of maintenance is 83 percent or 4-5 times higher than the cost of construction. A study by [11] signifies the main driver of economic growth, the role of maintenance. In many countries, it represents nearly $50 \%$ of the construction industry's total turnover [12]. Therefore, it is very important to reduce the effect of development factors that affect maintenance costs. In order to achieve cost-effective maintenance model, this work aims to classify the development factors affecting maintenance cost and rate these factors in order of importance. Standard design techniques are not pretty enough nowadays to solve multidisciplinary issues, so developers need to be informed about individual relationships. The absence of this high intake of design defects appears to increase the non-value adding demolition and repetitive work inevitably result in higher maintenance costs [13].

According to [14], Maintenance costs on the US market are projected to increase by $5.6 \%$ annually to almost US\$ 95 billion in 2011. In contrast, this percentage is $8 \%$ in Malaysia, and the Malaysian government has counted a large amount of money for repair, maintenance and renovation work. In terms of value, the cost of maintenance in 2013 was about MYR8.218 billion, representing about 9 percent of the total cost of construction. In one research [15] described that in the last decade, up to 50 percent of the infrastructure budget was spent on repair and maintenance projects in the construction industry in the United States, but this situation has now changed and spending has dropped to 25 percent [16]. This indicates that the repair and. maintenance sector is important in the USA. There are many studies in literature focusing on the identification of causes and effects of design in maintenance practice all over the world, including [17] in the USA; [18] in Denmark; [19] and [20] in Malaysia; [21] in the UK; [14] in Hong Kong;[22] in the Gulf countries and [23] in Saudi Arabia. Work in the area of categorization and analysis of model deficiencies is based on very little or no attempt to effectively manage highway projects. Deficiencies in development have a direct negative effect on overrun costs and plan delays, disagreements and rework[24]. However, several of the generic models developed can facilitate design process [25]; [26] and [27] but cannot be adopted as a basis for systematic assessment of design defects.

\section{B. Highway Maintenance}

A study by [28] it is possible to classify maintenance as planned and unplanned. Further planned maintenance subdivided into two main sub-categories: planned preventive maintenance involving work to prevent failure of a facility to ensure continued operation and planned corrective maintenance after a failure. [29] who further sub-divided planned preventative maintenance into scheduled and condition-based maintenance. Figure 1 provides an overview of the classification of maintenance. American Association of State Highway and Transportation Officials [30] define road maintenance terminologies as follows:

Preventive Maintenance: Preventive maintenance is a planned cost-effective treatment program that protects and retains or enhances a road system and the degradation of its appurtenances and delays, but without significantly increasing structural efficiency. Preventive maintenance is a tool for non-structural treatments for pavement preservation to be applied early in a pavement's life to prevent deterioration. In other words, preventive maintenance applies the right treatment to the right pavement at the right time.

Reactive Maintenance: Reactive maintenance involves activities that respond to circumstances beyond the control activities of an organization, such as patching potholes, rut filling, or drainage unplugging. Therefore, reactive maintenance is unplanned; often there is a need for immediate response to avoid serious consequences.

Emergency Maintenance: If life and property are at risk, extreme conditions require emergency maintenance. Examples include washouts, rigid pavement blow-ups (shattering or buckling upward of concrete slabs along a joint), and rockslides or earth slides.

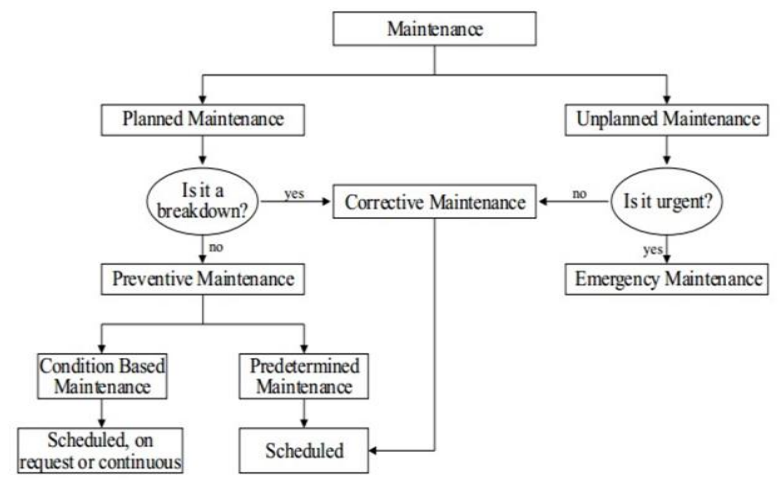

Fig. 1. Type of maintenance [28]

\section{Road Type in Malaysia}

Road is known as National Highway, State Highways, Major District Highways, Minor or Other District Highways and Village Highways. In the basis of administration, feature of through road and road layout standard, Malaysia highway road can be categorized. According to function Malaysian roads divided in two groups one is rural and other is urban roads. Urban road is graded as four such as expressway, arterial, collector, local lane. There are also five graded rural roads known as expressways, highways, main roads, secondary roads, minor roads. All roads consist of two components which is pavement or carriageway, shoulders. pavement or carriageway has consisted of subsoil, subbase, base, surfacing. The other component of road consists of traffic separators, kerbs, footpaths, parking lanes, cycle tracks, guard rails and fencing.[31]

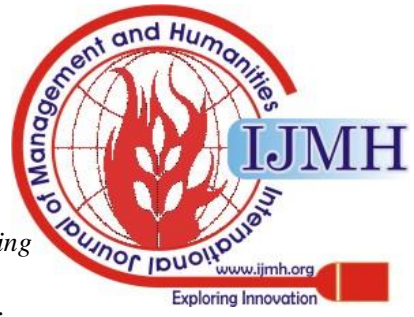




\begin{tabular}{|c|c|c|c|}
\hline \multicolumn{5}{|c|}{ Malaysia Road Design Standard } \\
\hline $\begin{array}{c}\text { Design } \\
\text { Standard } \\
\text { (Rural) }\end{array}$ & Categories & $\begin{array}{c}\text { Design } \\
\text { Standard } \\
\text { (Urban) }\end{array}$ & Categories \\
\hline$R 6$ & Expressway & U6 & Expressway \\
\hline$R 5$ & Hightray, Primary Road & U5 & Atterial \\
\hline$R 4$ & Primary Road, Secondary Road & U4 & Minor Atterial, Major Collector \\
\hline$R 3$ & Secondary Road & U3 & Collector, Major Local Streets \\
\hline$R 2$ & Minor Roads & U2 & Local Streets \\
\hline$R 1$ & Chances of tro way flow is low & U1 & Chances of tro way flow is low \\
\hline$R$ la & Local access to low cost housing areas & Ula & Local access to restricted areas \\
\hline
\end{tabular}

Fig. 2. Road Classification of Malaysia[31]

\section{Road Maintenance factors}

Policies and funding for operation and maintenance (O\&M) have been found to be an important factor in the likely sustainability of projects, including those in the transport sector. In 2001-2009, 35 percent are considered less likely or unlikely to be sustainable, even some rated effective or successful, for sovereign projects and programs with completion reports from $\mathrm{ADB}[32]$. A successful assessment of pricing and financial viability, accompanied by O\&M policies and financing, were the main factors supporting a most likely ranking. A poor assessment of the policy and regulatory environment and O\&M policies and funding were the main factors for an unsustainable score. In addition, inadequate support for O\&M was a major factor in a low sustainability rating for the transport and information and communications technology (transport) market, whereas strong institutional capability and technical expertise was correlated with a high sustainability score. Unlikely classified development ventures had a higher share of non-revenue-generating operations. Other key issues related to an adequate balance between network expansion investment and increasing maintenance requirements for existing roads; high axle loads; and insufficient funding, particularly at subnational levels that did not have the human or financial resources to cope with It was concluded that it was important to raise public awareness of the concept of maintenance and its benefits through user and community participation; maintenance financing required a sector- and country-level fiscal assessment, including borrowing capacity; and sustainability involved traffic management, particularly truck design and axle-load regulations and their enforcement [32] For 22 developing Member States with road sector operations, a document analysis was undertaken to explore in more detail the main maintenance issues in the road transport sector. Documents for programming, approval, and evaluation relate to the 2009-2012 period. In some instances, supplementary information was also used from other departments and sources. The 16 maintenance factors identified are 174 observations (Table 1). Eight of these issues happened in at least 11 countries each, reflecting the top half of the issues that have been posed. Four of the higher ranking issues related to the planning, identification and

prioritization of maintenance activities, including inadequate maintenance, overloading of trucks, poor road design, and standards, and limitations of the road asset management system. Three issues ranked in the top half with respect to capacity in the road maintenance process; a lack of qualified personnel by number or capacity; insufficient involvement of the private sector in road maintenance; and, more generally, a lack of institutional capacity with regard to road maintenance planning, execution and financing. The only issue common to all 22 countries was the lack of sufficient funding for road maintenance.[32] Such eight problems in the higher rankings are listed show in fig.3.

\begin{tabular}{llll}
\hline \multicolumn{1}{c}{ Factors } & $\mathrm{N}$ & $\%$ & Rank \\
\hline A. Maintenance Planning Factors & & & \\
- Inadequate maintenance & 18 & 10 & 2 \\
- Overloading & 17 & 10 & 3 \\
- Poor road design & 12 & 7 & 7 \\
- Road asset management system & 11 & 6 & 8 \\
- Untimely maintenance & 7 & 4 & 10 \\
- Limited construction materials & 4 & 2 & 15 \\
B Maintenance Capacities Factors & & & \\
$\quad$ - Limited capacity and number of qualified staff & 17 & 10 & 3 \\
- Lack of Institutional Capacity & 15 & 9 & 5 \\
- Need for strong private sector participation & 15 & 9 & 5 \\
- Weak governance & 8 & 5 & 9 \\
- Transparency/risk of corruption & 7 & 4 & 10 \\
- Lack of quality contractor & 6 & 3 & 12 \\
- Lack of advanced technology & 6 & 3 & 12 \\
C Financing Factors & & & \\
- Lack of funding & 22 & 13 & 1 \\
D Other Factors & & & \\
- Natural disaster & 5 & 3 & 14 \\
- War/conflict & 4 & 2 & 15 \\
& $\mathbf{1 7 4}$ & $\mathbf{1 0 0}$ & \\
\hline
\end{tabular}

Fig. 3. Factors in road maintenance[32]

\section{E. Recent cost model for Operation and Maintenance}

A comprehensive literature study on the fast-growing facilities management discipline shows that different models have been developed based on the Balance Scorecard (BSC), Business Excellence Model (BEM), Key Performance Indicator (KPI), and Capability Maturity Model (CMM), etc. Although these models come from different backgrounds, each of them has made impressive progress towards improving the performance of organizations. This can be seen from various efforts made by a significant number of researchers and experts to use these models in their own fields. This presents and explores in depth the comparison of existing four models (BSC, BEM, KPI and CMM) and a detailed literature review of construction and FM. Clear emphasis on managing and increasing property costs in this discipline, workspace-related service and a new term added value has been introduced. This paper typically conceptual and attempts to identify the prevailing model in facilities maintenance practice. Nonetheless, it is developed on a large scale of research and empirical evidence. From the extensive literature study of the conceptual model, the value-adding concept is often included and discussed the various parameters.

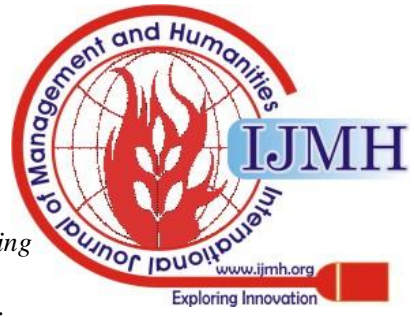


Table 1: Scholar study on main components of the cost model

\begin{tabular}{|c|c|c|c|c|}
\hline SL & Cost Model & Objective & Main focusing Area & Authors \\
\hline 1 & $\begin{array}{l}\text { Business Excellence Model } \\
\text { (BEM) }\end{array}$ & $\begin{array}{l}\text { Reinforce the organization's } \\
\text { operational planning. }\end{array}$ & $\begin{array}{l}\text {-Financial } \\
\text {-Customer satisfaction } \\
\text {-Business process } \\
\text {-Service } \\
\text {-Community } \\
\text { - Environmental }\end{array}$ & [33]-[35] \\
\hline 2 & $\begin{array}{l}\text { Business Excellence Model } \\
\text { (BEM) }\end{array}$ & $\begin{array}{l}\text { Describes cause-and- effect of an } \\
\text { operational process }\end{array}$ & $\begin{array}{l}\text {-Financial } \\
\text {-Customer satisfaction } \\
\text {-People satisfaction } \\
\text {-Impact on society } \\
\text {-Policy and strategy } \\
\text {-Resources }\end{array}$ & {$[35],[36]$} \\
\hline 3 & $\begin{array}{l}\text { Key Performance Indicator } \\
\text { (KPI) }\end{array}$ & $\begin{array}{l}\text { Focuses on critical aspects of } \\
\text { outcomes/ outputs }\end{array}$ & $\begin{array}{l}\text {-Cost } \\
\text {-Quality } \\
\text {-Safety } \\
\text {-Productivity } \\
\text {-Profitability } \\
\text {-Customer satisfaction } \\
\text {-Safe environment } \\
\text {-Service reliability }\end{array}$ & [33], [35] \\
\hline 4 & $\begin{array}{l}\text { Capability Maturity Model } \\
\text { (CMM) }\end{array}$ & $\begin{array}{l}\text { Helps to improve current best } \\
\text { practices of the organization }\end{array}$ & $\begin{array}{l}\text {-Capability } \\
\text {-Maturity } \\
\text {-Process management }\end{array}$ & [33], [37] \\
\hline
\end{tabular}

Table 2: Identified various value parameter for cost model

\begin{tabular}{|c|c|c|c|c|c|c|c|c|}
\hline References & [38] & [39] & [40] & [41] & [42] & [43] & [44] & [45] \\
\hline Category & A & B & C & D & $\mathbf{E}$ & $\mathbf{F}$ & G & H \\
\hline $\begin{array}{c}\text { People } \\
\text { satisfaction }\end{array}$ & $\begin{array}{l}\text { Customer } \\
\text { satisfaction }\end{array}$ & $\begin{array}{l}\text { Focusing on } \\
\text { talented staff }\end{array}$ & $\begin{array}{l}\text { User } \\
\text { satisfaction }\end{array}$ & Satisfaction & $\begin{array}{l}\text { Satisfaction } \\
\text { Culture }\end{array}$ & Satisfaction & $\begin{array}{l}\text { User } \\
\text { satisfaction } \\
\text { Culture }\end{array}$ & $\begin{array}{l}\text { Users } \\
\text { satisfaction } \\
\text { Culture }\end{array}$ \\
\hline $\begin{array}{l}\text { Financial } \\
\text { condition }\end{array}$ & $\begin{array}{l}\text { Value of } \\
\text { assets }\end{array}$ & & $\begin{array}{l}\text { Finance } \\
\text { position }\end{array}$ & & & $\begin{array}{l}\text { Value of } \\
\text { assets }\end{array}$ & & $\begin{array}{c}\text { - } \\
\text { Increasing } \\
\text { asset value }\end{array}$ \\
\hline $\begin{array}{c}\text { Organizational } \\
\text { development }\end{array}$ & $\begin{array}{l}\text { Flexibility } \\
\text { Innovation }\end{array}$ & $\begin{array}{l}\text { Interaction } \\
\text { Culture } \\
\text { Creativity }\end{array}$ & $\begin{array}{l}\text { Culture } \\
\text { Image } \\
\text { Innovation }\end{array}$ & $\begin{array}{c}\text { Adaptation } \\
\text { Culture } \\
\text { Reliability }\end{array}$ & $\begin{array}{l}\text { Adaptability } \\
\text { Reliability }\end{array}$ & $\begin{array}{c}\text { Innovation } \\
\text { Flexibility }\end{array}$ & $\begin{array}{l}\text { Image } \\
\text { Flexibility } \\
\text { Innovation }\end{array}$ & $\begin{array}{l}\text { Image } \\
\text { Innovation } \\
\text { Collaborati } \\
\text { on }\end{array}$ \\
\hline Productivity & $\begin{array}{c}\text { Productivit } \\
\mathrm{y}\end{array}$ & $\begin{array}{l}\text { Enhancing } \\
\text { productivity }\end{array}$ & $\begin{array}{l}\text { Improving } \\
\text { productivity }\end{array}$ & Productivity & Productivity & $\begin{array}{l}\text { Increase } \\
\text { productivity }\end{array}$ & Production & \\
\hline $\begin{array}{l}\text { Environmental } \\
\text { responsibility }\end{array}$ & & $\begin{array}{l}\text { Environmental } \\
\text { impact }\end{array}$ & & $\begin{array}{l}\text { Environmen } \\
\text { tal }\end{array}$ & $\begin{array}{c}\text { Social } \\
\text { Environmental }\end{array}$ & $\begin{array}{c}\text { Environmental } \\
\text { sustainability }\end{array}$ & & \\
\hline Cost efficiency & $\begin{array}{l}\text { Reducing } \\
\text { cost }\end{array}$ & $\begin{array}{l}\text { Reducing } \\
\text { cost }\end{array}$ & $\begin{array}{l}\text { Reducing } \\
\text { cost }\end{array}$ & $\begin{array}{l}\text { Cost } \\
\text { minimizatio } \\
\mathrm{n}\end{array}$ & Reduce cost & $\begin{array}{c}\text { Reduce } \\
\text { cost }\end{array}$ & $\begin{array}{c}\text { Cost } \\
\text { control }\end{array}$ & $\begin{array}{l}\text { Decreasing } \\
\text { cost }\end{array}$ \\
\hline
\end{tabular}

Table 3 illustrates the main parameters that were discussed in the various cost model

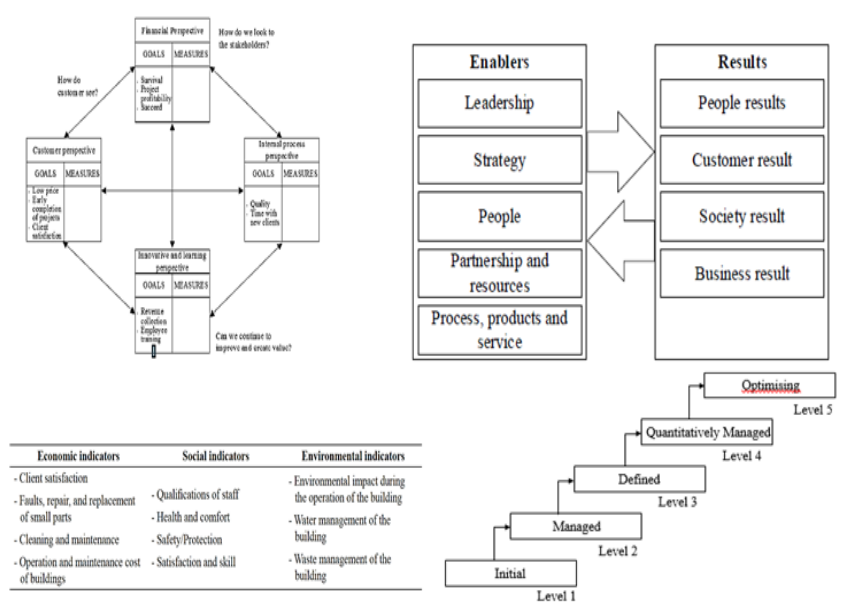

Fig 4. Cost Model [34]-[36], [46]

\section{METHODOLOGY}

In order to achieve the cost-effective design parameters from the operation and maintenance process to the design development team, the author performed various research related activities, including: discussing the substantial role of facilities management throughout the life cycle of the highway project, defining the impact of design failure costs on the post-occupancy stage. Critically evaluated current method for constructing highway projects. Exploring the role of facilities management throughout the operation and maintenance of the design process and facilities. In addition, a wide-ranging literature review requires a specific notice collecting all possible references in order to obtain cost-saving metrics, based entirely on the theoretical analysis approach. Since, as mentioned above, due to design errors that are deemed necessary for the project development stage, there has been a lack of studies on the cost of maintainability increasing element. For the purpose of determining the factors, applicable articles containing reference due to profound analysis. This portion of the evaluation involved "differentiating and combining" the evidence collected [24]. Importance was put on the interpretation of the expressions, not on the words themselves.

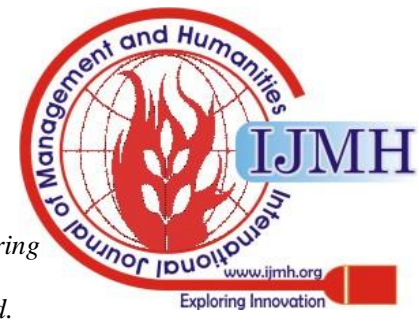


From now on, all the recognized factors will be sorted into similar categories irrespective of their classification. The use of "inductive coding technique" will be used. Furthermore, the methodology section referred to the approach of preparing qualitative data. Since the purpose of this study is to understand in detail the different cost parameters found by researchers from a variety of fields, the correct method used to be the analysis of material. Content analysis is the just frequent approach when analysing texts [25]. Therefore, this study also looked-for references to fulfilment factors without identifying so.

The data collection section for literature analysis concerned an in-depth inquire of dense foremost journals consisting of however not restrained to, as outlined below: Journal of Management in Engineering, Journal of Transportation Engineering, Transport Policy, Engineering Construction and Architectural Management, Jordan Journal of Civil Engineering Journal of Civil Engineering and Management, Journal of Construction Engineering and Management Science and Technology for the Built Environment. Other than the mentioned above, the subsequent databases additionally have been searched; Emerald, Web of Science, ASCE Online Library, Science Direct in addition Taylor and Francis Online. Collectively, many more journals be situated according to the field from above mentioned database. Furthermore, for searching used keywords were identified by authors preliminary literature review. Also, the articles were choice from journals to that amount had been peer-reviewed or else scholarly. However, the proper decision of the articles used to be based about the researcher's choice since analysing the article abstract then title. Prospective articles will be prioritized if contain some records indicating the research related cost factor.

\section{RESULT AND DISCUSSION}

The result obtained from the preliminary analysis of cost models are summarized in Table 3 . This table is quite revealing in several ways. From this table, we can see that all models consider the satisfaction parameter under the "people satisfaction" related category. Of the 8 models which analyzed on this research, 3 models C, G and H was very specific on "user satisfaction", in model A only reported on "customer satisfaction". Model E, G and H also include "culture", while model B is only focused on the "talented staff" under people satisfaction. As a result, people related design parameters are well accepted by most of the model as they have realized the significance of incorporation to FM model development.

The most striking result to emerge from the Table 3 is that the total number of models for this study agreed the parameter "reducing cost" under "cost efficiency" category with slightly different terms. Model G is only presented to some extent different name of the parameter called "cost control", indirectly this term is also referred the mostly viewed wide-ranging parameter "reducing cost". This indicates a common view amongst model that cost-effectiveness is the most prioritized parameters all kind of business organization in terms of capital investment, turnover and operational cost. Obviously, cost reduction is an important mean in building operational phase without regard to the harm being done to occupants' comfort and satisfaction as well as the global environment. Initial capital investment for building facilities is a major concern, however, now a day long-term cost impacts for built facilities are measuring and benchmarking in terms of affordability and sustainability (Turner, 2016).

From the Figure 6, bar chart graph illustrates the number of parameters considering in the model. It can clearly be seen that "user satisfaction" parameter was a considerably utmost

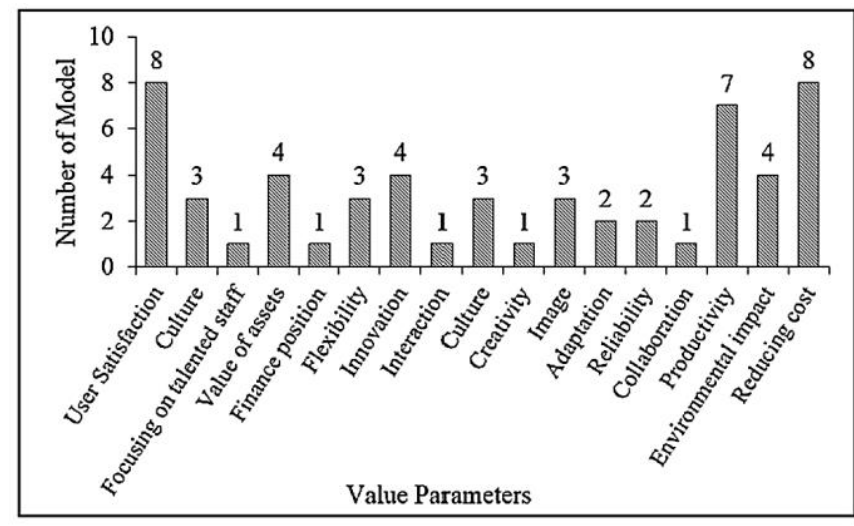

Fig 5: Parameters in each model

priority as all model adopted this, similarly the "reducing cost" parameter also accepted as it is the goal of the organization. From the graph, it is apparent that except the single model, other models consider the "productivity" parameter. However, three parameters "value of assets", "innovations" and "environmental impacts" have the moderate effect on FM model creation as four models defined these parameters under a different category. Almost two-thirds of the models indicated the following four parameters namely "culture", "flexibility" and "image". Together these parameters provide important insight into a conceptual model of facilities management. Based on the mentioned parameters in Table 3, the 11 value parameters are listed and organized in Table 4 with four headings. More or less all the value parameters in Table 3 are included from the comprehensive literature study of the FM model, however, the terms of the parameters have been synchronized. In addition, the parameter "health and safety" has been added under the people heading.

Table 3: Identified parameters in different group

\begin{tabular}{lclll}
\hline \multicolumn{1}{c}{ Group } & \multicolumn{1}{c}{ People } & Process and Product & \multicolumn{1}{c}{ Economy } & \multicolumn{1}{c}{ Social } \\
\hline Value & - Client and user & - Productivity & -Cost-effectiveness & - Environmental \\
Parameters & satisfaction & - Design adaptability & - Value of asset & impact \\
& - Practiced culture & - Innovation and & & - Responsibility \\
& - Health and safery & creativity & & \\
& & - Risk management & & \\
\hline
\end{tabular}

\section{CONCLUSION}

Management cost model is a fast-growing discipline throughout the world, and now it is imperative to build up the cost model field not only by being able to deliver similar services at a reduced cost as before, but also by offering better services to their valued customers and end users. In this paper, a thorough literature review is performed to evaluate the quality parameters from the systematic analysis of the theoretical cost models developed over the past 10 years.

Blue Eyes Intelligence Engineering \& Sciences Publication

(C) Copyright: All rights reserved. 
The existing 8 conceptual models are observed in the context of facilities management based on the literature study and quite diverse parameters have been revealed in the research projects of variants. These parameters found have a tremendous impact on cost conceptual model awareness. The $\mathrm{KPI}$ is commonly used by management practitioners as opposed to KPI, BSC, BEM and CMM. The results from this study, such as the template created, the facilities management team will recognize the identified shortcomings and gaps in expertise to assist them in implementing appropriate education and training and in developing new mindsets and attitudes to sustainability efforts. The small number of conceptual models analyzed in the facilities management discipline is a major limitation. Clearly, for the specific industry, all current models are illustrated with their own specific characteristics. Cost model management is a discipline, however, with its own specific features. Therefore, Further study may be carried out to collect more empirical data so that greater reliability will be provided for the results of data analysis.

\section{ACKNOWLEDGEMENT}

The author would like to thank the Ministry of Education (MOE) Malaysia through Research University Grant (RUG) No 1501 UTM funding project title Development of Biocement Using Ex Situ Mixing Technique for Construction Materials, for financial assistances while conducting this research project.

\section{REFERENCES}

1. W. S. Alaloul, M. S. Liew, and N. A. W. A. Zawawi, "Identification of coordination factors affecting building projects performance," Alexandria Eng. J., 2016.

2. V. Dixit, M. K., \& Venkatraj, "Integrating Facility Management Functions in Building Information Modeling (BIM): A Review of Key Issues and Challenges.," IRC 2017, p. 597, 2017.

3. M. mail Online, "PLUS spent RM1b in 2016 to maintain highways, says," 2018.

4. J. W. Bull, "The way ahead for life cycle costing in the construction industry.," Blackie Acad. Prof. Glas. UK., 1993.

5. J. D. Flanagan, R., Norman, G., \& Furbur, "Life cycle costing for construction," Surv. Publ., 1989.

6. Wan Imran Wan Omar., "Evaluating lifecycle cost (LCC) and performance between cold in-place recycling (CIPR) and reconstruction method. Unpublished master dissertation, Kulliyah of Architecture and Environmental Design.International Islamic University, Malaysia.," 2015.

7. S. Z. Ayob, M. F., Abdul Rashid, K., Bidi, N.K. and Ahmad Jasmi, "Identification of cost data inputs in Life Cycle Cost (LCC) of alternative road pavement types (profile of final report of RAGS project for Ministry of Education Malaysia)Research Report. (Unpublished).," 2017.

8. N. A. A. Rahman, S. B. A. \& Salim, "A Study on Design Defects Affecting Maintenance.," in 5th Undergraduate Maintenance and Facilities Management Conference 2013, 2013.

9. M. Love, P. E. D., Lopez, R., Kim, J., \& Kim, "Influence of organizational and project practices on design error costs.," J. Perform. Constr. Facil., vol. 28, no. 2, pp. 303-310, 2014.

10. T. Ohara, S. and Asada, "Japanese project management - Hackensack, NJ: World Scientific.," 2009.

11. M. Kamaruzzaman, S.N., Myeda, N.E., Pitt, "Performance levels of high-rise private office buildings maintenance management in Malaysia," Eksploat. I Niezawodn. Maint. Reliab., vol. 15, no. 2, pp. 111-116, 2013.

12. O. A. Lateef, "Building maintenance management in Malaysia," $J$. Build. Apprais., vol. 4, no. 3, pp. 207-214, 2009.

13. M. M. Wan, S. K. M., and Kumaraswamy, "Improving building services coordination at the pre-installation stage," Eng. Constr. Archit. Manag., vol. 19, no. 3, pp. 235-252, 2012.

14. M. Tan, Y., Shen, L., Langston, C., Lu, W., \& CH Yam, "Critical success factors for building maintenance business: a Hong Kong case study.," Facilities, vol. 32, no. 5/6, pp. 208-225, 2014.

15. D. (2009). Lee, H. H. Y., \& Scott, "Overview of maintenance strategy, acceptable maintenance standard and resources from a building maintenance operation perspective.," J. Build. Apprais., vol. 4, no. 4 pp. 269-278, 2009.

16. A. S. Ali, "Cost decision making in building maintenance practice in Malaysia,” J. Facil. Manag., vol. 7, no. 4, pp. 298-306, 2009.

17. E. Erdener, "Linking Programming and Design with Facilities Management.," J. Perform. Constr. Facil. February,Erlandson., pp. 4-8, 2003.

18. P. A. Jensen, "Design Integration of Facilities Management: A Challenge of Knowledge Transfer," Archit. Eng. Des. Manag., vol. 5 , pp. 124-135, 2009.

19. F. Ali, A. S., Keong, K. C., Zakaria, N., Zolkafli, U., and Akashah, "The effect of design on maintenance for school buildings in Penang, Malaysia," Struct. Surv., vol. 31, no. 3, pp. 194-201, 2013.

20. C. Yap, J. B. H., Low, P. L., \& Wang, "Rework in Malaysian building construction: impacts, causes and potential solutions," J. Eng. Des. Technol., vol. 15, no. 5, pp. 591-618, 2017.

21. X. Meng, "Involvement of Facilities Management Specialists in Building Design: United Kingdom Experience," J. Perform. Constr. Facil., vol. 27(October, pp. 500-507, 2013.

22. H. M. Jawdeh, "Improving the integration of building design and facilities management (Doctoral dissertation, University of Salford).," 2013.

23. M. O. Hassanain, M. A., Adewale, B., Al-Hammad, A. M., \& Sanni-Anibire, "Factors affecting building services coordination during the design development and review stages," Built Environ. Proj. Asset Manag., vol. 8, no. 1, pp. 64-77, 2017.

24. S. M. Song, L., Mohamed, Y., and AbouRizk, "Early contractor involvement in design and its impact on construction schedule performance," J. Manag. Eng., vol. 25, no. 1, pp. 12-20, 2009.

25. M. A. Mohammed, M. A., \& Hassanain, "Towards improvement in facilities operation and maintenance through feedback to the design team," Built Hum. Environ. Rev., vol. 3, pp. 72-87, 2010.

26. J. Love, P. E., Edwards, D. J., \& Smith, "Systemic life cycle design error reduction model for construction and engineering projects," Struct. Infrastruct. Eng., vol. 9, no. 7, pp. 689-701, 2013.

27. I. Mutalib, A. F., Sapri, M., \& Sipan, “An assessment model of FM organisational performance," Facilities, vol. 36, no. 3/4, pp. 212-226, 2018.

28. P. Chanter, B. and Swallow, Building Maintenance Management. 2nd Ed. Oxford: Blackwell Publishing Ltd. 2007.

29. I. H. Seeley, Building Maintenance,. 1987.

30. AASHTO, "Maintenance Manual for Roadways and Bridges," 2007.

31. Hamizan, "MALAYSIAN ROADS," 2019.

32. ADB, "ISSUES IN ROAD MAINTENANCE," 2013.

33. T. M. Bassioni, H.A., Price, A.D.F. and Hassan, "Performance measurement in construction," J. Manag. Eng., vol. 20, no. 2, pp. 42-50, 2004.

34. M. T. Phadtare, "Developing Balanced Scorecard: Case of three construction firms of small size. Journal of Asia-Pacific Business," J. Asia-Pacific Bus., vol. 11, no. 2, pp. 135-157, 2010.

35. M. Meng, X., \& Minogue, "Performance measurement models in facility management: a comparative study.," Facilities, vol. 29, no. 11/12, pp. 472-484, 2011.

36. J. Kauppila, O., Mursula, A., Harkonen, J., \& Kujala, "Evaluating university-industry collaboration: the European Foundation of Quality Management excellence model-based evaluation of university-industry collaboration," Tert. Educ. Manag., vol. 21, no. 3, pp. 229-244, 2015.

37. S. Chrissis, M.B., Konrad, M. and Shrum, "CMMI: Guidelines for Process Integration and Product Improvement.," Boston, Addison-Wesley, 2003.

38. \& H. Lindholm, A. L., "A constructive study on creating core business relevant CREM strategy and performance measures," Facilities, vol. 26, no. 7/8, pp. 343-58, 2008.

39. H. J. van Meel, J., Martens, Y., \& van Ree, "Planning office spaces: a practical guide for managers and designers: L. King.," 2010.

40. J. Van der Zwart, "Hospital real estate management in a changing context.PhDthesis.," 2014.

41. C. Jensen, P., van der Voordt, T., Coenen, B. von Felten, D., Lindholm, A.-L., and M. Nielsen, S., \& Pfenninger, "In search for the added value of FM: what we know and what we need to learn.," Facilities, vol. 30, no. 5/6, pp. 199-217, 2012.

\section{Published By:}

Blue Eyes Intelligence Engineering

\& Sciences Publication

(C) Copyright: All rights reserved. 
42. S. B. Jensen, P. A., Nielsen, K., \& Nielsen, "Facilities Management best practice in the nordic countries: 36 cases:," Cent. Facil. Manag. Res., 2008.

43. A. Lindholm, A.-L. and Aaltonen, "Green FM as a way to create value. Chapter 12 in: Jensen et al. eds. The Added Value of Facilities Management - Concepts, Findings and Perspectives.," Cent. Facil. Manag. - Realdania Res. DTU Manag. Eng. Polytek. Forl., pp. 195-204, 2012.

44. T. de Vries, J. C., de Jonge, H., \& van der Voordt and J., "Impact of real estate interventions on organisational performance.," J. Corp. Real Estate, vol. 10, no. 3, pp. 208-223, 2008.

45. A. C. Den Heijer, "Managing the University Campus: Information to support real estate decisions:," Eburon Uitg. BV., 2011.

46. D. Amaratunga, D., Haigh, R., Sarshar, M. and Baldry, "Assessment of facilities management process capability: a NHS facilities case study," Int. J. Health Care Qual. Assur., vol. 15, no. 6, pp. 277-88, 2002.

\section{AUTHORS PROFILE}

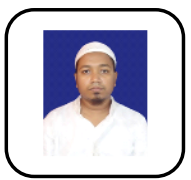

Monirul Islam is currently a graduate research assistan at the Department of Quantity Surveying, Universiti Teknologi Malaysia, Johor Baharu, Johor. The author obtained his first degree in civil engineering in 2011 at the Bangladesh University of Engineering and Technology (BUET), Dhaka, Bangladesh. He has been working as an assistant engineer at Local Government Engineering Department (LGED). The research area is on Development of Operation and Maintenance Cost Model for Highway Projects. He is register Civil Engineer certified by the Institution of Engineers, Bangladesh. Now he attends a MPhil program in Quantity Surveying at the Universiti Teknologi Malaysia. He has more than 8 years of working experiences in field works in the consultancy firm, government and semi-government projects.

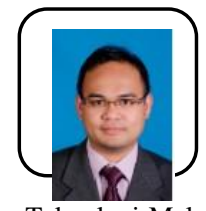

Associate Professor Sr Dr. Sarajul Fikri Mohamed is an academic staff at the Department of Quantity Surveying, Universiti Teknologi Malaysia, Johor Baharu, Johor where he specializes in Construction Management, Project Estimating and Construction Innovation. He obtained B.Sc. in Quantity Surveying from Universiti Teknologi Malaysia (UTM). In the year 2002, he completed his Master of Science in Construction Innovation and $\mathrm{PhD}$ in Construction Management in 2006 from Loughborough University, United Kingdom. His research areas include construction procurement, construction innovation and commercial management in construction. Prior to this, he worked as property and construction consultant at MDA Consulting UK. The examples of projects he was involved in are Stratford Western Relief Road (Warwickshire County Council), William Baker Building (University of De Montfort), Airfield Business Park Market Harborough (William Davis), and Sport Complex Building (Leicestershire County Council). He has more than 17 years working experiences in related field.

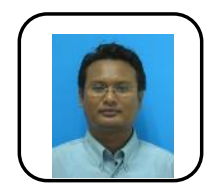

Senior Lecturar Sr Dr. Syamsul Hendra Bin Mahmud is an academic staff at the Department of Quantity Surveying, Universiti Teknologi Malaysia, Johor Baharu, Johor where he specializes in Construction safety and health, Construction technology and advanced construction, Construction measurement and Sustainable construction innovation. He obtained Diploma and B.Sc. in Quantity Surveying from Universiti Teknologi Malaysia (UTM). In the year 2002, he completed his Master of Engineering Science in Construction Management from University of New South Wales, Sydney, Australia. He obtained PhD from Universiti Teknologi Malaysia. His research areas include construction safety and health, construction technology and advanced construction, construction measurement and sustainable construction innovation.

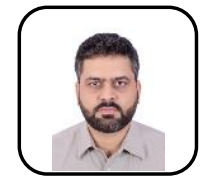

My name is Khalid Alghamdi I am from Makkah, Saud Arabia. I studied Design and earned a bachelor's degree in Graphic Design from Umm Al-Qura University in 2007. Since then, I have been working as a teacher assistant at the Graphic Design department at the same university. While working as a teacher assistant, I participated in several researches, studies, and design projects at Excellence in Haj and Umra Research (CEHOR) and other centers in Saudi Arabia. In 2010, based on excellence in work and effort he received a full scholarship at the University of New South Wales in Sydney. Then in 2012, he earned a Master's degree in Design from the University of New South Wales college of Fine Arts in 2012, also I work as a contemporary artist and I have a lot of art projects acquired from the Saudi Contemporary Museum in Riyadh and Ather gallery and Hafez Gallery in Jeddah. Now I attend a Ph.D. program in urban and regional planning at University Technology Malaysia.

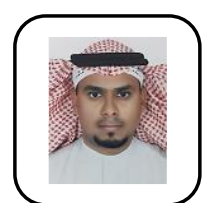

My name is Abdullah Karban I am from Makkah, Saudi Arabia. I studied Architecture and earned a bachelor's degree in Architecture from Umm Al-Qura University in 2008. Since then, I have been working as a teacher assistant at Islamic Architecture department at the same university. While working as a teacher assistant, I participated in several researches, studies and design projects at Excellence in Haj and Umra Research (CEHOR) and other centers in Saudi Arabia. In 2013, I worked as a Graduate Research Assistant at the Center for Urban and Regional Planning Research, at The University of Texas at San Antonio. Then in 2014, I earned a master's degree in Urban and Regional Planning from The University of Texas at San Antonio. In 2015, I worked at prince Khaled Al-Faisal Chair for developing informal areas in Makkah region. Now I attend a Ph.D. program in urban and regional planning at University Technology Malaysia. 